受動とは……させられることで，環境の作用をうけて その後の反応が中絶させられるのが金属体の受動態であ る。鉄は希硝酸には

$$
2 \mathrm{Fe}+4 \mathrm{HNO}_{3}=2 \mathrm{Fe}\left(\mathrm{NO}_{3}\right)_{2}+2 \mathrm{H}_{2}
$$

なる反応で活性状態で溶解して腐食するが，浱硝酸中 では

$$
2 \mathrm{Fe}+6 \mathrm{HNO}_{3}=\mathrm{Fe}_{2} \mathrm{O}_{3}+3 \mathrm{~N}_{2} \mathrm{O}_{4}+3 \mathrm{H}_{2} \mathrm{O}
$$

なる反応で受動態となって不溶となる。 $\mathrm{Fe}$ と $\mathrm{HNO}_{3}$ の割合 $1: 1$ で活性で鉄は溶解するが， $1: 3$ となると きは, 硝酸の働きをうけて表面に安定なる $\mathrm{Fe}_{2} \mathrm{O}_{3}$ 薄層 を生じて溶けなくなる。一般に金属体表面に酸化物の安 定なる薄層を生じるとき，または安定なる化合物薄層を つくって耐食的になるのが受動態なのである。それに対 し不動態とは酸素を溶存しない希硫酸中に銅を浸した場 合のように，銅と希硫酸中の硫酸分子のそれぞれの含む エネルギーの差がある限度以下に小さくて相互に働かず に腐食の進まない場合で immunity（不感受性）ともい うべき状態である。

受動態ということは，金属元素の原子が規則正しく前 後・左右・上下に配列した形ある金属体表面における特 長で，環境中の物質との反応を受けて，安定なる化合物 の薄層を生じるために現われる現象であって，この現わ れの機構もはっきりと化学方程式で示されるのである。

金属体の腐食は活性状態すなわち能動態で進み，不動 態と受動態とで耐食的であるわけになる。不動態と受動 態とは同じではなく別のことなのである。

以前には金属体の passive state は受動態と訳されて おりななくなれた東北大学の遠藤彦造博士も受動態と
いう言葉を使われていた。ところが，昭和 6 年に日本化 学会が不用意にも passive state を不動態としたので, それにならって今日の混乱がもたらされたのである。し かし，金属体の passive state は正しく受動態で不動態 とは本質的にちがうことである。同じ passive state を 受動態としたり，不動態として混乱していることはよろ しくない。しかも不動態では意味をなさないのであるか らここに passive state を受動態として統一したいと 提案して，皆さんの御意見を求める次第である。
討 論
司会 多賀谷正義*

岡本剛（北大工）私も御意見どおり，受身である之 いうことから受動態の方がよいと思います。私は「不動 態化」と言っている。

多賀谷 私も passive state を受動態とするのが本当 だと思う。ここで受動態と不動態について，参会のみな さんはどう思われるでしょうか。このままで，混乱させ ておいてよいとは思わない。

山本 用語というものは専問的にとりあつかわれなけ ればならない。用語の混乱は現象の原因についての見方 を䛊まらせる。

岡本 フランス語では passivité が不動, passivation が受動（不動態化）という意味に区別しているが，これ もまぎらわしいので, passivité はやめて immunité と して用いているようである。

山本 Passiveを受動，immunityを不動とするなら ば，確かにはっきりしてょいと思う。（整理 大塚陸郎）

* 大阪大学工学部

\title{
電気防食における陰極の防食電流の意味についで**
}

\author{
提案者山本 洋 一***
}

すでに電気防食は海中施設や地中埋設鉄管などの防食 のために大切な仕事となっている。しかしながら, 電気 防食において陰極とした金属製品がいかにして腐食しな くなるかの理由は明らかでない。陰極とした金属体表面 に対する電流密度をある程度以上にすること，あるいは 電極電位をある限度以下にすれば防食の目的を達成でき るというが，これも経験的な結果であって，電流密度の 電極電位之の相互の関係あることも確かである。問題は 電気防食における陰極の防食電流の意味を明らかにする ことである。電気的に防食ができるというが，電気とは

** 昭和 33 年 11 月 第 2 回防食技術研究討論会において発表

*** 日本大学理工学部
何かが実はわかっていないことを知らなくてはならな い。

陰極の電流密度をある程度以上にすることおよび電極 電位をある限度以下にすれば防食できるという意味につ いてはっきりさせたいというのが，この討論の目的であ る。

電気防食は電解質水溶液を必要条件とする院極金属体 の防食で陰極防食というのも，このためである。電気防 食は電気分解現象をもととして行なわれることで電気 分解現象の真相を知ることによってはじめて電気防食が いかにして行なわれるかのわけも明らかになるのであ る。これまでのごとく,電気分解が電流の作用であって， 
電解質水溶液の電流を通じるのは, 水溶液中の電解質が 電気をおびたイオンに分れているためであるというので は, 電気を仮定しており, 電気とは何かを明らかにして いない今日では完全なる説明にはならない。ここにおい て私は電解質が分解するので回路の金属体にいわゆる電 流が生じるのだとし，電解質を分解させるためには，電 解質分子における金属原子（または金属的水素）の回路 の金属体を通じてての質量移行を認め, 質量移行をさせる 力としてエネルギー粒子の蓄積（これが浴電圧として測 定させる）を考元，電解質の分解において回路の金属体 を流動するエネルギーの粒子の数が電流となるとするの である。この見解については,すでに防蝕技術昭 33.5 月 号 130 136 p において述べている。ところで，ここで エネルギー粒子というのは, プランク常数 $\mathrm{h}$ であって,

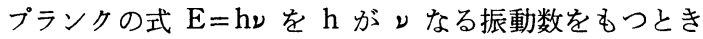
に E なる仕事をすると解釉し，働きを現わす能力とし て定義されたェネルギーの粒子を認めるのである。これ までの一般の考え方では土ネルギーと仕事とが混同さ れ，h⿻ をもってェネルギーとして，エネルギーの単位 は erg であるとしているが，ここに誤まりがあると私 はいうのである。

プランク常数 $\mathrm{h}$ は粒子として，この宇宙にスキマな くみちみちて万物をつくり万象を現わす根元であって, 働きを現わす能力と定義されるエネルギーである。 $\mathrm{h}$ は $6.624 \times 10^{-27} \mathrm{erg} \mathrm{sec}$ なる一定の值をもつ粒子であり, フクラミ・チヂムという性質を有している。空間におけ るエネルギー粒子の分布の不同（歪み）あるいはマダラ が万物をつくり，万象をあらわしているのである。

電気といわれる現象には静電気と動電気とがあるとい う。しかしながら, 今日の実用の電気は, ボルタの電池 の発明から得られた現象で, 回路に金属体を必要条件と することであって，その正体は流動するh の粒子の状態 である。1 A $1 \mathrm{sec}$ に h が $7.6 \times 10^{38}$ 個の流動で $1 \mathrm{~V}$ は $1 \mathrm{sec}$ に h の数 $7.6 \times 10^{38}$ 個の差のあることである。
電池作用においては陽極とした 金属体の含むエネル ギーが陰極のそれより大にして, 回路の金属体で流動し て, 陰極より電解質水溶液に入りこみ, 電解質を陽極表 面におしつけて, 電気分解して電流を生じる。外部電源 は回路にエネルギーを供給して，それを流動させて，陽 極で電気分解を起させるときに電流を生じさせる。陰極 と陽極との含むェネルギー差が浴電圧としてはかられ， 生じる電流の方向は, エネルギーの流動のそれと反対で ある。陰極より陽極にむけて流動するエネルギーは陰極 表面より電解質分子をおしはらって，陰極金属との働き を起させなくする。この陰極より液中に流動するェネル ギーの大きさがある程度以上になって防食するときの值 が，いわゆる防食電流となるのである。陰極とした金属 体を防食するに必要な電流密度とは, 陰極より流動して 電解質分子との反応を抑制するようになったときの働き を現わす能力である h の粒子の数である。基準電極によ って測定する電極電位の低下は, 陰極に加わったエネル ギーと基準電極のエネルギーとの差であって, 陰極の含 むエネルギーの大となったことで，電流密度と正比例は しないが関係をもっているので，防食勃果を知るに役立 つわけである。

陰極表面より水溶液中に流動するエネルギー粒子の数 により, 局部電池の構成も打ち消されて, 局部腐食も抑 制されるのである。

このようにして, 電気防食における防食電流は, 電気 化学的腐食理論でいわれるような, 陽極と陰極との局部 電池の電流を打消すということだけではない。電流の正 体を明らかにして，流動するェネルギーによって陰極表 面より電解質をおしのけることが電気防食の可能なる理 由である。

\section{討喰司会 多賀谷正義*}

日下武（海上自衛隊）電気の正体を明らかにされた 結論は面白い。

（整理 大塚陸郎）

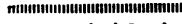 \\ 新刊紹介}

中川雅央 : “海中施設の電気防钟”発行所：日本港湾協 会（東京都新宿区四谷 1 の 13)，34 年 3 月, A 5 版, 140 ページ

\section{“Metal Finishing Abstracts"}

発行所: Robert Draper Ltd., Kerbihan House 85, Udney Park Road, Teddington, Middx, England 本誌は世界の主要工業国における 600 の定期刊行物か ら採録した表面仕上げ関係の文献調査を目的とするもの で，年間 6 冊の予定で本年 $1 \sim 2$ 月号から発行されてい
る。

(H.S.)

"Cleaning and Passivation of Corrosion-Resisting Steels" (PB 131964)

"Effect of Halide Addition to the Sulfuric Acid Pickling Bath" (PB131794)

以上 2 冊とも米国海軍のまとめた特殊鋼の表面洗浄方 法に関する解説書で 各 75 セントで頒布されている。

発行所: Office of Technical Services, U.S. Dept. of Commerce, Washington, 25, D.C.

(H.S.) 